UDK: 330.322:338.124(497.11)

Originalni naučni rad
POSLOVNA EKONOMIJA

BUSINESS ECONOMICS

Godina XV

Broj 1

Str $60-70$

doi: 10.5937/poseko19-33230

Milan Cvetkov, PhD student ${ }^{1}$

Educons University, Sremska Kamenica - Novi Sad,

Faculty of Business Economics

\title{
NEW APPROACHES IN INVESTMENT RISK MANAGEMENT IN PUBLIC SECTOR IN THE POST- CRISIS PERIOD: A CASE STUDY OF THE REPUBLIC OF SERBIA
}

\begin{abstract}
The subject of the research in this paper is giving an overview, description and analysis of the new approach in risk management of public sector investment, with a special focus on the Republic of Serbia as a domestic economy. The crisis of 2008 resulted, among other things, in an overall abandonment of neoliberal approach to market, and a complete redefining of market relationships, place and role and significance of particular participants in market. These new market circumstances have in particular affected the market position of public sector along with its market performance. Therefore, the main goal of this research in this paper is getting new knowledge, which can be validated in practice, about new approaches to management of public sector investment risks in post-crisis period, with a special focus on the Republic of Serbia and its public sector. The results of the research should provide new knowledge on modalities and effects of new approaches in management of public sector investment risks in the post-crisis period, thus enabling an effective and efficient repositioning of the place, role and significance of the public sector on the market of the Republic of Serbia. In this way they will be useful to the academic community in broadening the scientific data base in this area of interest, as well as policymakers
\end{abstract}

${ }^{1}$ milancvetkov011@gmail.com 
in the process of defining and implementing of public sector policies.

Key words: public sector, risk management, investment, postcrisis period, the Republic of Serbia

\section{INTRODUCTION}

Contemporary market circumstances are in many respects specific and unusual. Their specific features are a result of the fact that there is no clear public concept of economic policy of bringing about an order to market and market relationships, which leads to having market conditions and relationships which resulted from unregulated, undefined rules with no clearly expressed direction for the further development of market and market related policies. Since leaving the Keynes concept of market arrangement, which was based on a statist approach, with the state standing in the foreground as a market participant, the liberal concept from around the middle of the 1980s has been dominant and widely accepted one of market regulation, which is based on a belief that market has the ability to self-regulate, and that the role of the state is to create conditions for the development of the market and growing of wealth. This concept became fully implemented in the middle of the 1970s, being a dominant pillar of economic policy until the economic crisis of 2008. In the meantime, it went through certain modifications, although it remained basically unchanged. This concept, which was named Liberal afterwards, (probably alluding to its promptness and flexibility in the real economic moment), totally collapsed when the economic crisis of 2008 broke out. One by one, the market participants turned to the state, asking for and expecting to be given support. In order to keep some sort of stability of markets and their economies, at least at a superficial level, states answered in a positive way, and they have supported market participants actively and with significant sums. Thus, we can see a form of neo-statism and a great comeback of the state to the market.

The position and significance of public sector considerably change in such market circumstances. Unlike the previous role it had, public sector is no more seen as a mere provider of services to the state, whose role is to provide for the needs of the public as well as to collect public goods, and is becoming to be seen as an important market participant, bearing in mind the scope of the means it manages along with a constant need to for various investment activities. These circumstances are particularly becoming prominent in case of the economies of developing countries, as highly volatile markets with low liquidity and efficiency. Therefore, the subject of the research in this work is giving an overview, description and analysis of new 
approaches in public sector investment risks, with a special focus on the Republic of Serbia as a domestic economy. Our research will particularly deal with the ways the public sector of the Republic of Serbia manages investment risks, bearing in mind the tasks it has, as well as providing knowledge of the possibilities of improvement of investment policies of the public sector of the Republic of Serbia, in order to optimise investment risks and maximise effects of investment activities.

The main hypothesis of this research is that it is possible to create new approaches to public sector investment risks in post-crisis period, whose implementation will enable conditions for sustainable growth and development.

The main goal of this research is to get concrete knowledge, which can be validated in practice, about new approaches to public sector investment risks in post-crisis period, with a special focus on the Republic of Serbia and its public sector. Such knowledge should enable policymakers to optimise the relationship between public sector investment risks and estimated effects of investment activities, while, at the same time, maximising the function of being of advantage to public. History proves the fact that, as a rule, public sector's flexibility is low, that it is less effective than the private sector, and that new, altered market circumstances call for a change of the market position of public sector, which involves repositioning of its policy of market performance as well as particulars of its business activities management. This is especially important for making decisions related to investment activities and their validation, in order to optimise the relationship between investment risks and maximising investment effects. This also has a particular importance in case of developing countries, because their markets constantly face a lack of finance, which makes the optimisation of the previously mentioned relationship particularly important in the light of a changing market position of public sector. Realising and assessment of possibilities to apply new approaches in public sector investment risk management in actual post-crisis market circumstances becomes a necessity of the contemporary market milieu, especially in case of developing countries such as the Republic of Serbia.

This study is conceived in the next way: the introductory part gives a description of the subject and problem of the research, pointing out its main aim. Then follows an overview of bibliography related to the area of interest. The third part brings an analysis of the current market situation, the market position, role and significance of public sector, followed by an attempt to focus on a new paradigm of public sector investment risk management, particularly in the Republic of Serbia, which is to enable creation and application of new approaches in public sector investment risk management. This is all followed by concluding remarks and selected bibliography. 


\section{THEORETICAL BACKGROUND}

A wide range of bibliography related to the area of interest must be analysed in order to provide a relevant theoretical base for the research. Domestic sources will mostly be in focus, considering the way the research is conceived, with an addition of researches by foreign authors as well.

Dašić (2018, pp. 14-18) gives an analysis and account of contemporary trends in the development of public sector in which he finds that entrepreneurial and business concept of public management, as an introduction to the quality system of public services, is becoming the fundamental objective of all reforms of administration. Jovanović (2020) points at a very important fact that the public sector in the Republic of Serbia still stays predominantly centralised in decision making process, being focused on administrative responsibility, while at the same time neglecting results and performance.

Đuričin and Đukić (2017, pp. 99-101) in their study deal with the financial performance of selected public enterprises. The results of their research point at a need to find individualised ways in order to define measures that lead to improvement of financial aspect of operation of the selected public enterprises. This finding is of particular importance in order to make a further analysis of public sector, which can be applied to any individual public enterprise as an entity for itself. However, a logical question arises in connection with a possible success of such approach, because only integrated, coherent, systemic and coordinated market performance can lead to positive effects of public sector reforms.

Themsen and Skaerbaek (2018, pp. 24-28) show that for a successful management of challenges associated with risks, it is required that technologies be constantly adjusted in order to enable long term stability. This means that flexibility is necessary if public sector is to be efficient and effective in contemporary market circumstances.

Caperchione, Demirag i Grossi (2017, pp. 3-5) in their study deal with public and private partnership as a specific form of organisation on the market, pointing at new directions of development of this form of organising, taking notice of possible dilemmas they cause.

This research is made more updated by taking referent sources in the area of interest into consideration, bearing in mind possible challenges in front of public sector and its investment policies in developing countries. 


\section{OPEN QUESTIONS REGARDING THE POSITION, ROLE AND SIGNIFICANCE OF PUBLIC SECTOR IN CONTEMPORARY MARKET CIRCUMSTANCES}

Public sector can be defined in various ways. This research's aim is to observe the position, role and significance of public sector through the prism of market and its market participation rather than to offer different approaches to defining public sector. This way of looking into the matter enables us to take public sector as equal as any other market participant, and see its position, role and significance in contemporary market circumstances in an optimal manner.

Historically speaking, public sector's position has changed both within market and society in general. There was a time when public sector was seen as an incredibly important and dominant market subject or "the long arm of the state". Then there came the notion of its market position, which was considerably derogated, taking public sector as a necessary, but not important market factor, especially in terms of fulfilling certain public goods goals, with no real market significance. Such view was formed partly due to public sector itself, having behaved in a way which was inflexible, languid, lacking the interest to adjust to market conditions, and expecting the opposite instead. At the times of the domination of the liberal market concept, such expectations were neither realistic nor likely. So, once an important market subject in Keynes era, public sector became pushed aside and looked upon as an inefficient and ineffective" arm of the state". To be honest, public sector seemed to feel comfortable in that role. Such situation remained for rather long, and it was only in 2008 when the crisis imposed the need for market repositioning. The period of crisis made everyone turn to the state as a last resort, which subsequently made a considerable increase in public sector investment one other main ways of support given by the state, apart from direct subventions. This brought back the prominence of the policy of public works and Keynesian concept of market ordering. Therefore, there are authors who are prone to using the term "New-Keynesian" in order to designate the period after the breakout of the crisis. Yet, although public sector has experienced a sort of revival, we cannot speak of a Neo-Keynesianism here.

Active inclusion of the state in market developments has resulted in a number of changes, among which redefining and repositioning of public sector's market position seems to be particularly important. A logical question arises of the readiness of the public sector for the new role. Is public sector sufficiently capacitated for an efficient and effective new role, or the old notion of its being inflexible, inefficient in terms of organisational capacity will prove to be true? Many questions remain unanswered and still the period from 2008. until today leaves little room for optimism. Although 
public sector has large financial means at its disposal, it still shows slowness, low efficiency and efficacy, burdened with the reputation it had in previous periods. These characteristics are especially observable in developing countries. What is the reason for this? On the one hand, we are talking about highly volatile markets with low efficiency, and on the other, even in the period before the crisis their public sector had been characterised with a number of challenges from the past, which not only never became resolved, but even increased in size. Therefore, the main motivation for this research comes from an attempt to use a systemic approach in order to get an insight into the new market position of public sector (primarily in developing countries), and then suggest new approaches to public sector investment risk management. It is undisputable that only optimal use of resources can help create a realistic basis for sustainable growth and development of economy, which in practice requires new approaches to public sector investment risk management in the post-crisis period.

Thus, it makes it possible to create prerequisites for a successful repositioning and redefining of the role public sector plays in contemporary market circumstances, turning it into an active, dynamic and modern market subject.

\section{NEW APPROACHES TO PUBLIC SECTOR INVESTMENT RISK MANAGEMENT: THE CASE STUDY OF THE REPUBLIC OF SERBIA}

Investment risks can be of a variety of kinds. The same is true for risks in general. How can we describe or define risks? What does it mean to manage risk? The easiest way to define risk is to say that it refers to any aberration from what was expected or planned. In other words, all aberrations of this kind can be taken as risk. If, for example, we understand that a crisis can be taken as a kind of mistake in an assumed continuity, then risk, according to this logic, is a prerequisite for a crisis to break out. So risk is directly related to crisis. This actually means that to manage risk is to manage a crisis, its occurrence and development.

Risk cannot be eliminated, but it can be managed in order to reduce it to an acceptable level. Of course, there is the question of the level which can be accepted. This means that reducing the risk to an acceptable level is an attempt to keep the level of the crisis acceptable. This is the reason why the topic of risk management has been given a special significance since the break out of the crisis. This also means that in order to manage crisis efficiently, one has to validate the risk as well as to keep it acceptable. 
The next big issue is related to investment risk. It is well known that there is no growth and development without investing and that the absence of growth and development leads to stagnation and decline. Since investing is a necessity of contemporary market, optimisation of the effects of investment activities and their usefulness should be in focus. This can only be accomplished by managing investment risk in an optimal way, which means that there is a constant need to improve the approach and models of investment risk management.

We cannot talk about investment activities risk management without taking into consideration an important fact of who is the subject of investment, i.e. who leads the investment activities. Contemporary market circumstances have turned public sector companies into investment subjects of premier importance. This would have sounded incredible about a decade ago, but the current market reality proves to be quite the opposite. Since the crisis broke out public sector has become an important if not the main factor of investment activities, particularly in developing countries like the Republic of Serbia. Therefore, the market effect of new approaches in public sector investment risk management is manifold.

It can be seen in:

- the position of public sector in market relationships,

- creating the base for sustainable growth and development,

- providing the real basis for the growth of employment,

- increased market efficiency.

This influence is even more intensive in developing countries due to their specific market features. So the goal of new approaches in public sector investment risk management is taking into consideration the above mentioned issues, while at the same time avoiding making them restrictive factors in investment policy. The point is that in current conditions of recession any reduce in public sector investment activities results in negative consequences for market stability, and the stability of entire economies, which makes developing countries particularly vulnerable in this respect.

New approaches in risk investment are supposed to be able to incorporate a number of significant, market-oriented modules, namely:

- module of optimal organisation of public sector (module I)

- module of efficient and effective approach to the assessment of investment alternatives (module II)

- module od neodogmatic views and opinions about the future of market and market relationships (module III)

- module of social policies and social protection expenditure (module IV) 
This could be schematically presented in the following way:

Figure 1.
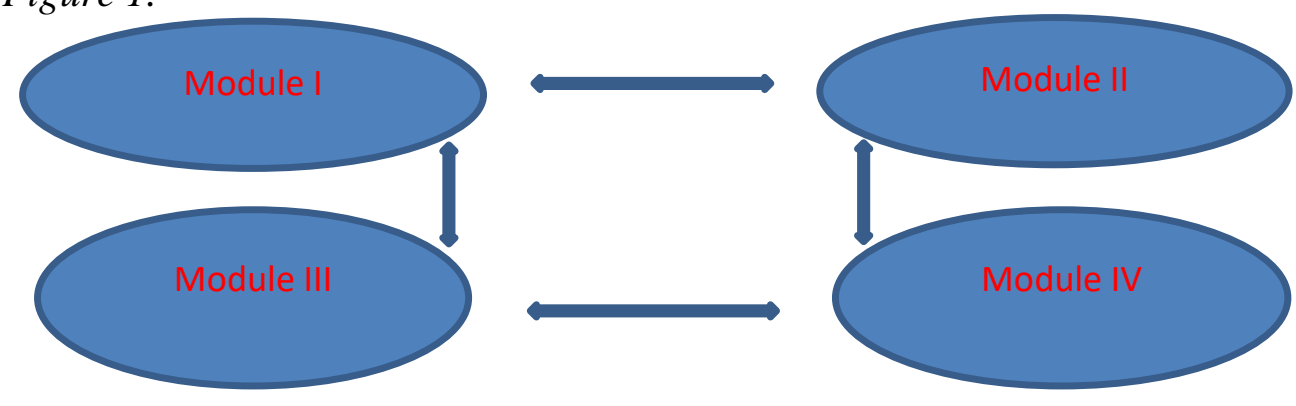

Source: Author

New approaches in public sector investment risk management in the post-crisis period with a focus on developing countries (the Republic of Serbia in particular) should not miss to recognise the four modules mentioned above, which stand for four factors they represent. Only this can lead to realistic expectations in connection with the future ability of public sector to carry out repositioning process within market relationships in order to become an efficient market subject and bearer of the growth and development of economy. So, an overall systemic redefining of the way public sector is organised should be done, both at macro and micro levels, in order to make it more flexible, more proactive and more rational.

The next thing to do is to change the approaches of validation and assessment of possible investment alternatives. The approaches that have been used so far, i.e. the traditional ones, are no longer optimal enough in the contemporary post-crisis market conditions, and they should be made more flexible and efficient. In general, redefining the view on market and market relationships is utterly important, because the experience we have had so far alongside actual market circumstances have proved that already existing dogmatic views are not enough to cope with the reality of the moment. Last but not least, social policies should be reconceived in the way suitable for the new market reality and creation of preconditions for social stability and fairness.

All that has been stated above can be used as the basis for creating new approaches to public sector investment risk management in the post-crisis period, with a special insight in what is going on in developing countries and the Republic of Serbia, and their further application in practice. Realistic preconditions for changes can be created by approaching the problem in a systemic and comprehensive way; therefore, it would be highly preferable to start the implementation of the right activities as soon as possible. 


\section{CONCLUDING REMARKS}

The research in this study has been done with aiming at gaining concrete knowledge about new approaches in public sector investment risk in the postcrisis period, with a special interest in developing countries i.e. the Republic of Serbia. This has resulted in the creation of a genuine base of knowledge, the practical use of which could enable public sector to reposition itself and change its contemporary market role and significance, while at the same time creating conditions for sustainable growth and development.

The basic hypothesis of the research implies the notion that it is possible to create new approaches to public sector investment risk management, whose implementation will create the conditions for sustainable growth and development, has proved to true, which necessitates doing further researches in this area of interest.

The goal of the research has been achieved by gaining actual knowledge which can be validated in practice, especially in connection with the Republic of Serbia and its public sector's new approaches to investment risk management in the post-crisis period.

Contemporary market circumstances constantly pose new increased challenges to all market participants. Having in mind the market importance of public sector, it is of a particular significance to gain pragmatic insight, and implement this knowledge in order to help optimise market sector's market position as well as maximise public sector investment effects. The effort in this research has been made as an attempt to broaden the base of information in this field of interest, both in order to help further research and to help creators of public policies in their everyday tasks.

The challenges which the author had to face during the research primarily originate from the fact that there is a shortage of previous studies of the subject of the position of public sector in contemporary market circumstances, notably in developing countries, but they have been overcome due to a systemic approach to the area of study and an overall analysis of conditions of both public sector and market.

Further research activities will be directed towards a more minutious and comprehensive analysis of public sector in developing countries, paying special attention to introduction of innovated approaches to public sector investment risks, aiming at even more optimised effects of such investment activities. 


\section{REZIME \\ NOVI PRISTUPI UPRAVLJANJU RIZICIMA INVESTIRANJA JAVNOG SEKTORA U POST-KRIZNOM PERIODU: STUDIJA SLUČAJA REPUBLIKA SRBIJA}

Predmet istraživanja u radu jeste sagledavanje, opisivanje i analiziranje novih pristupa upravljanju rizicima investiranja javnog sektora, sa posebnim fokusom na Republiku Srbiju kao domaću ekonomiju. Kriza iz 2008. godine je, između ostalog, za svoju posledicu imala i potpuno napuštanje neoliberalnog pritupa tržištu, odnosno potpuno redefisanje tržišnih odnosa, mesta, uloge i značaja pojedinih tržišnih učesnika na njima. Ove nove tržišne okolnosti su naročito uticale na poziciju javnog sektora na tržištu i njegov nastup na njemu, pa je otuda osnovni cilj istraživanja koje se namerava realizovati u ovome radu dolaženje do konkretnih, u praksi validiranih saznanja o novim pristupima upravljanju rizicima investiranja javnog sektora u postkriznom periodu, naročito se fokusirajući na Republiku Srbiju i njen javni sektor. Rezultati istraživanja treba da omoguće nova saznanja o modalitetima i efektima novih pristupa upravljanju rizicima investiranja javnog sektora u post-kriznom periodu, omogućavajući na taj način efikasno i efektivno repozicioniranje mesta, uloge i značaja koji javni sektor ima na tržištu Republike Srbije. U tom smislu, oni će biti korisni kako akademskoj javnosti za širenje naučne baze u oblasti, tako i kreatorima politika $u$ procesima formulisanja i implementiranja politika u javnom sektoru.

Ključne reči: javni sektor, upravljanje rizicima, investiranje, post-krizni period, Republika Srbija.

\section{REFERENCES}

1. Afonso, S., (2003). Public sector efficiency, an international comparison, European Central Bank working paper series no 242; Afonso, S. (2006), Public sector efficiency: evidence for new EU member states and emerging markets, European Central Bank working paper series no 581.

2. Andrews, R., (2010). New Public Management and the Search for Efficiency. In: T. Christensen and P. Laegrid (eds), Ashgate Research Companion to the New Public Management. Ashgate Press: Aldershot, pp281-94.

3. Afonso, S., (2003). Public sector efficiency, an international comparison, European Central Bank working paper series no 242. 
4. Afonso, S., (2006). Public sector efficiency: evidence for new EU member states and emerging markets, European Central Bank working paper series no 581 .

5. Eugenio Caperchione, Istemi Demirag, Giuseppe Grossi, (2017). Public sector reforms and public private partnerships: Overview and research agenda. Accounting Forum, Volume 41, Issue 1, Pages 1-7,

6. Dašić, G., (2018). Savremeni trendovi u razvoju javnog sektora. Srpska akademska misao, broj 5, pp 7-25.

7. Đuričin, S., Đukić, M., (2017). Ocena ekonomsko finansijske moći odabranih javnih preduzeća u Republici Srbiji. Opportunities for inclusive and Resilient Growth: tematski zbornik. Institut ekonomskih nauka, Beograd, pp. 89-104.

8. Jovanović, P., (2020). Izazovi upravljanja i motivacije u javnom sektoru u Srbiji. Edicija Zbornici. Institut društvenih nauka. Beograd, pp 118-139.

9. Madžar, Lj., (2015). Gordijev čvor javnih preduzeća u Srbiji: Drešiti ili seći? Restrukturiranje javnih preduzeća u uslovima institucionalnih ograničenja, Ekonomski fakultet, Beograd.

10. Nedić, V., Despotović, D., Cvetanović, S., Đukić, T., Petrović, D., (2020). Insitutional reforms for economic growth in the Western Balkan Countries", Journal of Policy Modeling, Volume 42, Issue 5, pages 933 952.

11. Tim Neerup Themsen, Peter Sk $\tilde{A}_{i} r b \tilde{A}_{i} k$, (2018). The performativity of risk management frameworks and technologies: The translation of uncertainties into pure and impure risks. Accounting, Organizations and Society, Volume 67, Pages 20-33,

12. Veselinović, P., (2014). Reforma javnog sektora kao ključna determinanta uspešnosti tranzicije privrede Republike Srbije, Ekonomski horizonti, Volumen 16, Sveska 2, $141-159$.

Ovaj rad je primljen 24.05.2021., a na sastanku redakcije časopisa prihvaćen za štampu 28.06.2021. godine. 